\title{
A Concise Synthesis of Berkelic Acid Inspired by Combining the Natural Products Spicifernin and Pulvilloric Acid
}

\author{
Christopher F. Bender, Francis K. Yoshimoto, Christopher L. Paradise, and Jef K. De \\ Brabander \\ Department of Biochemistry and Simmons Comprehensive Cancer Center, The University of Texas \\ Southwestern Medical Center at Dallas, Dallas, Texas 75390-9038
}

\begin{abstract}
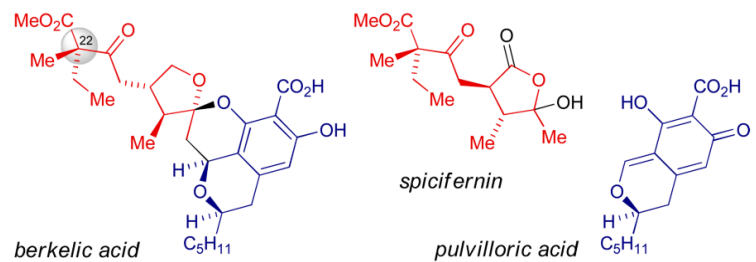

We describe a concise synthesis of the structurally novel fungal extremophile metabolite berkelic acid - an effort leading to an unambiguous assignment of C22 stereochemistry. Our synthetic approach was inspired by the recognition that berkelic acid displays structural characteristics reminiscent of two other fungal metabolites, spicifernin and pulvilloric acid. Based on this notion, we executed a synthesis that features a Ag-catalyzed cascade dearomatization-cycloisomerizationcycloaddition sequence to couple two natural product inspired fragments. Notably, a spicifernin-like synthon was prepared with defined C22 stereochemistry in seven steps and three purifications (24$28 \%$ overall yield). A potentially useful anti-selective conjugate propargylation reaction was developed to introduce the vicinal stereodiad. An enantioconvergent synthesis of the other coupling partner, the aromatic precursor to pulvilloric acid methyl ester, was achieved in eight steps and 48\% overall yield. The total synthesis of berkelic acid and its C22 epimer was thus completed in 10 steps longest linear sequence and $11-27 \%$ overall yield.
\end{abstract}

Berkeley Pit Lake in Montana, a 30 billion gallon flooded copper mine and largest superfund clean-up site in the United States, is an unlikely source of structurally novel natural products. Yet, this highly acidic, heavy-metal contaminated poisonous broth harbours microbial life, including an extremophilic Penicilium fungus that produces the unique tetracyclic chroman/ isochroman spiroketal berkelic acid (Fig. 1). This compound, isolated by Stierle et al in 2006, was found to possess selective activity against the human ovarian cancer cell line OVCAR-3 $\left(\mathrm{GI}_{50} 91 \mathrm{nM}\right)$ and moderate inhibitory activity against the matrix metalloproteinase MMP-3 $(1.87 \mu \mathrm{M})$ and the cysteine protease caspase-1 $(98 \mu \mathrm{M}){ }^{1}$

The stereochemistry of berkelic acid was originally assigned as shown in structure $\mathbf{1}$ on the basis of NMR experiments, although the configuration at the quaternary stereocenter $\mathrm{C} 22$ and absolute configuration were left undetermined. Recently, the Fürstner group reported studies leading to a revision of the relative stereochemistry of berkelic acid as shown in structure 2 through total synthesis of the corresponding methyl ester. ${ }^{2}$ Through elegant synthetic, NMR, and crystallographic studies, they further revealed that the originally proposed relative 
stereochemistry does not represent a thermodynamic minimum because of a key syn-periplanar interaction between the C25 methyl substituent and C16 methylene group. ${ }^{3}$ Subsequently, Snider and coworkers reported their total synthesis of berkelic acid, which established its absolute configuration as shown in $\mathbf{2}$, and putatively assigned the stereochemistry at the quaternary center as C22-S. ${ }^{4,5}$ Herein, we wish to report a concise synthesis of the two C22 epimers of berkelic acid (2) that fully corroborates the revised stereochemistry and unambiguously resolves the remaining issue of $\mathrm{C} 22$ stereochemistry.

Our approach was inspired by the recognition that the original assigned berkelic acid structure 1 represents a formal combination of the natural products spicifernin ${ }^{6}(3)$ and pulvilloric $\operatorname{acid}^{7}\left(4\right.$, Scheme 1). ${ }^{8}$ Based on this notion, we developed a strategy that would emulate this hypothetical combination and designed a suitable spicifernin-like synthon such as enolether 7,9 available via metal-catalyzed cycloisomerization. ${ }^{10}$ Participation of this material in a [4+2] cycloaddition with the ortho-quinone methide tautomer 5 of pulvilloric acid (4) would deliver spiroketal 1. It did not escape our attention that this chemistry could potentially be implemented with minimal oxidation state adjustments. ${ }^{11}$

Given the ambiguity related to the absolute stereochemistry at C22, we opted for a synthesis that would enable access to the two C22 epimers of fragment 6 (Scheme 2). Starting with commercially available methyl 2-ethyl-3-oxobutanoate $(\mathbf{8})$, the corresponding $(L)-{ }^{t} \mathrm{Bu}$ valinate-derived enamine 9 was prepared ( $82-88 \%$ yield) and alkylated with methyl iodide to afford the $\alpha$-quaternary substituted imine derivative $\mathbf{1 0}$ with high stereoselectivity (>15:1 dr). 12 The absolute stereochemistry at C22 was determined by a single crystal X-ray diffraction analysis of the cyclic 4-bromo-2-nitrophenylhydrazone derivative $11 .{ }^{13}$ Continuing with the synthesis, hydrolysis of crude imine $\mathbf{1 0}$ was followed by a titanium tetrachloride-mediated dehydrative aldol reaction with (4-methoxybenzyloxy)ethanal yielding enone 12 in 42-45\% yield (3 steps) from enamine 9 . We explored various options to introduce the $\alpha$-methylsubstituted propargyl unit and settled on an approach that entails a conjugate addition of a metalated propargyl/allenyl species to enone 12. Although the stereoselective propargylation of aldehydes is well precedented, we could find only one example of the corresponding conjugate addition in the literature. ${ }^{15}$ After substantial experimentation, we found that addition of enone 12 to a cold $\left(-78{ }^{\circ} \mathrm{C}\right)$ dark red solution of a cuprate derived from adding (4(trimethylsilyl)but-3-yn-2-yl)lithium to a suspension of $\mathrm{CuBr} \cdot \mathrm{SMe}_{2}$ in TFEF $\left(-78{ }^{\circ} \mathrm{C}\right)$ efficiently effected the desired conjugate propargylation. ${ }^{16}$ Although the anti-selectivity was acceptable, the stereogenic quaternary center did not impart any facial selectivity, leading to an inseparable equimolar mixture of $R, S$ - and $S, R$-diastereomers 13a and $\mathbf{1 3 b} .{ }^{17}$ As such, this crude mixture was carried forward by treatment with methanolic potassium carbonate, followed by oxidative deprotection to yield compounds 14a,b. Proton NMR analysis of chromatographically homogeneous material (with correct elemental analysis), ${ }^{13}$ isolated in $70 \%$ yield from enone 12, indicated a complex mixture of equilibrating lactols and open-chain isomers. The corresponding mixture of enantiomers ent-14a,b was prepared from the $(D)_{-}{ }^{t} \mathrm{Bu}$ valinate-derived enamine ent-9, or cheaper, by switching the additive from THF to HMPA during the alkylation of $(L)^{-}{ }^{-} \mathrm{Bu}$ valinate-derived enamine $\mathbf{9} .^{12}$

A concise enantioconvergent synthesis of the precursor to pulvilloric acid $\mathbf{4}$ begins with a crosscoupling of triflate $\mathbf{1 6}$ - obtained from commercially available methyl 2,4,6-

trihydroxybenzoate $\mathbf{1 5}$ in $91 \%$ yield - with 1-heptenylboronic acid to afford styrene derivative 17 (91\% yield, Scheme 3). Installation of the homobenzylic alcohol was best achieved via oxidation with $m \mathrm{CPBA}$ of the MOM protected derivative of $\mathbf{1 7}$, followed by benzylic epoxide reduction. Racemic alcohol $\mathbf{1 8}$ was thus obtained in $76 \%$ yield for the three-step sequence. Screening of a set of enzymes to mediate a kinetic resolution identified a lyophilized formulation of a lipase from Alcaligenes sp. to effect the transesterification (vinyl acetate) with high enantioselectivity at $\sim 50 \%$ conversion. ${ }^{18}$ Alcohol $\mathbf{1 9}$ and acetate $\mathbf{2 0}$ were isolated in $51 \%$ 
and $46 \%$ isolated yield and $93 \%$ and $95 \%$ ee respectively. Alcohol 19 was easily recycled to the desired acetate $\mathbf{2 0}$ via Mitsunobu esterification (78\% yield). Simultaneous removal of the protecting groups was achieved via stirring in acidic methanol (quant.). Condensation of the resulting triol 21 with triethyl orthoformate according to an adapted procedure described for the synthesis of pulvilloric acid (4) yielded isochroman acetal 22 (99\% yield), the precursor to pulvilloric acid methyl ester. Although it has been reported that the carboxylic acid corresponding to 22 will yield pulvilloric acid (4) upon removal of ethanol under ultra high vacuum, ${ }^{7 \mathrm{~d}}$ we opted to explore Lewis acid-promoted in situ dearomatization of 22 as described below.

As noted above, we were intrigued by the possibility to effect in situ dearomatization of lactol 22 to pulvilloric acid methyl ester under conditions that would allow tandem $\mathrm{C}-\mathrm{C}$ bond formation with spicifernin-like fragment 14. We speculated that $\mathrm{Ag}^{+}$would have a proper balance of hard Lewis acidic properties to induce removal of ethanol from 22, and sufficient alkynophilic character to induce cycloisomerization of alkynol 14 to enolether 23 (Scheme 4). ${ }^{19}$ Gratifyingly, stirring a solution of lactol 22 ( 1 equiv.) and $\mathrm{AgSbF}_{6}$ (3.5 equiv.) in the presence of alkynols 14a,b (2.6 equiv.) resulted in the formation of methyl berkelate $\mathbf{2 6}$ (from 14a) and four additional diastereomeric berkelates 25 (from 14b) ${ }^{20}$ in a ratio of $\sim 6: 4$, indicating a slight kinetic preference for the formation of 26. We hypothesize that $\mathrm{AgSbF}_{6}$ instigated a reaction cascade involving: (1) in situ formation of ortho-quinone methide $\mathbf{2 4}, 21$ (2) cycloisomerization of $\mathbf{1 4}$ to enolether 23, and (3) coupling via [4+2] cycloaddition. ${ }^{22}$

Because the methyl berkelate diastereomers were not separable by chromatography, they were carried forward as a crude mixture. Although Fürstner and coworkers disclosed that they could not identify conditions for the selective deprotection of the methyl benzoate in the presence of the aliphatic methyl ester, ${ }^{2}$ we found that $\left(\mathrm{Bu}_{3} \mathrm{Sn}\right)_{2} \mathrm{O}$ in toluene accomplished the task when the reaction was interrupted at partial conversion. ${ }^{23}$ Berkelic acid $\mathbf{2}$ was thus isolated in $35 \%$ isolated yield (from lactol 22) at $70 \%$ conversion and $46 \%$ yield after one recycling (77\% based on theoretical maximum yield). Prolonged reaction times resulted in the formation of decarboxylated product 28 ( 4:1 mixture of C22 diastereomers). The corresponding C22- $R$ diastereomer 27 was prepared via an identical sequence from ent-14a,b and lactol 22 in $26 \%$ yield. Only C22-S diastereomer 2 displayed spectral data fully congruent with natural berkelic acid, ${ }^{1}$ thus establishing the complete stereostructure of this unique natural product for the first time. The rotation of synthetic $\mathbf{2}\left([\alpha]_{\mathrm{D}}=-76.7, c=0.06\right.$ in $\left.\mathrm{MeOH}\right)$ agreed with those for natural $\left([\alpha]_{\mathrm{D}}=-83.5, c=0.0113 \text { in } \mathrm{MeOH}\right)^{1}$ and Snider's synthetic berkelic acid $\left([\alpha]_{\mathrm{D}}=-115.5, c=\right.$ 0.55 in $\mathrm{MeOH}){ }^{4}$

In conclusion, we have achieved a highly convergent and efficient synthesis of berkelic acid that fully establishes the stereochemistry at C22 in a longest linear sequence of 10 steps and $11-27 \%$ overall yield from commercially available starting materials. Notably, we identified a unique Ag-catalyzed cascade dearomatization-cycloisomerization-cycloaddition sequence to couple two natural product inspired fragments, and a potentially useful anti-selective conjugate propargylation reaction.

\section{Supplementary Material}

Refer to Web version on PubMed Central for supplementary material.

\section{Acknowledgments}

This work was supported by the NIH (CA90349), and the Robert A. Welch Foundation. C.F.B. thanks the NIH for a postdoctoral Fellowship (T32CA12433401). We thank Dr. Vincent Lynch (UT Austin) for X-ray analysis. 


\section{References}

1. Sierle AA, Sierle DB, Kelly K. J. Org. Chem 2006;71:5357-5360. [PubMed: 16808526]

2. Buchgraber P, Snaddon TN, Wirtz C, Mynott R, Goddard R, Fürstner A. Angew. Chem. Int. Ed 2008; $47: 8450-8454$.

3. Huang and Pettus reached a similar conclusion on the basis of a model study; see: Huang Y, Pettus TRR. Synlett 2008:1353-1356. [PubMed: 19183702]

4. Wu X, Zhou J, Snider BB. Angew. Chem. Int. Ed 2009;48:1283-1286.

5. Fürstner and coworkers prepared both C22 diastereomers of berkelic acid methyl ester, but close spectral similarity and lack of an authentic sample precluded confident assignment. The Snider assignment is based on correlation to model compounds and thus remains to be confirmed.

6. (a) Nakajima H, Hamasaki T, Maeta S, Kimura Y, Takeuchi Y. Phytochemistry 1990;29:1739-1743. (b) Nakajima H, Fukuyama K, Fujimoto H, Baba T, Hamasaki T. J. Chem. Soc. Perkin Trans. 1 1994:1865-1869.

7. (a) McOmie JFW, Turner AB, Tute MS. J. Chem. Soc. C 1966:1608-1613. (b) Tanenbaum SW, Nakajima S. Biochemistry 1969;8:4622-4626. [PubMed: 5353117] (c) Barrett GC, McOmie JFW, Nakajima S, Tanenbaum SW. J. Chem. Soc. C 1969:1068-1069. (d) Rödel T, Gerlach H. LiebigsAnn./ Recueil 1997:213-216.

8. This notion may or may not have biosynthetic relevance - a question that remains to be answered. It is interesting to note that spiciferone A was isolated alongside berkelic acid. ${ }^{1}$ Spiciferone $\mathrm{A}$ was also isolated together with spicifernin from the phytopathogenic fungus Cochliobolus spicifer Nelson, ${ }^{6}$ and both were shown to derive from a common hexaketide precursor. Hence, the genetic machinery to produce the common precursor to spiciferone $\mathrm{A}$ and spicifernin is also present in the penicilium species that produces berkelic acid. For the biosynthesis of spiciferone A and spicifernin, see: Nakajima H, Fujimoto H, Matsumoto R, Hamasaki T. J. Org. Chem 1993;58:4526-4528.

9. Note that enolether 7 , required for berkelic acid synthesis, is at a lower oxidation state than spicifernin 3.

10. Liu B, De Brabander JK. Org. Lett 2006;8:4907-4910. [PubMed: 17020333]

11. Burns NZ, Baran PS, Hoffmann RW. Angew. Chem. Int. Ed 2009;45:2854-2867.

12. Ando K, Takemasa Y, Tomioka K, Koga K. Tetrahedron 1993;49:15-79-1588.

13. See supporting Information.

14. For a review on the propargylation of aldehydes, see: Marshall JA. J. Org. Chem 2007:8153-8166. [PubMed: 17595141]

15. Song Y, Okamoto S, Sato F. Org. Lett 2001;3:3543-3545. [PubMed: 11678703]

16. For an example of 1,2-additions to aldehydes with similarly prepared cuprates, see: Alouane N, Vrancken E, Mangeney P. Synthesis 2007:1261-1264.

17. We are currently exploring this potentially useful transformation. Model studies with the corresponding gem-dimethyl substituted conjugated $\beta$-ketoesters indicate that a $\gamma$-protected alcohol is required for high anti-selectivity. We are also exploring the possibility to impart facial selectivity with homochiral Marshall-type allenyl organometallic species. ${ }^{14}$ Results of these studies will be reported in due course.

18. For the use of this enzyme for the resolution of benzylic and homobenzylic alcohols, see: Naemura K, Murata M, Tanaka R, Yano M, Hirose K, Tobe Y. Tetrahedron Asymm 1996:3285-3294.

19. Yamamoto Y. J. Org. Chem 2007;72:7817-8152. [PubMed: 17579452]

20. Reaction of 14b leads to a berkelate with original assigned stereochemistry, which exists in equilibrium with $\mathrm{C} 15, \mathrm{C} 17$, and $\mathrm{C} 18$ epimers. ${ }^{2}$

21. A silver concentration-dependent equilibrium between pulvilloric acid methyl ester and $\mathbf{2 2}$ was observed by NMR (22, $\left.\mathrm{AgSbF}_{6}, \mathrm{CD}_{2} \mathrm{Cl}_{2}\right)$.

22. For a review on $o$-quinone methides, see: Van De Water RW, Pettus TRR. Tetrahedron 2002;58:53675405. [PubMed: 19079773]. For an application, see ref $^{3}$.

Supporting Information Available: Experimental procedures and characterization data for new compounds (PDF, CIF). This material is available free of charge via the Internet at http://pubs.acs.org. 
23. Mata EG, Mascaretti OA. Tetrahedron Lett 1988;29:6893-6896. 

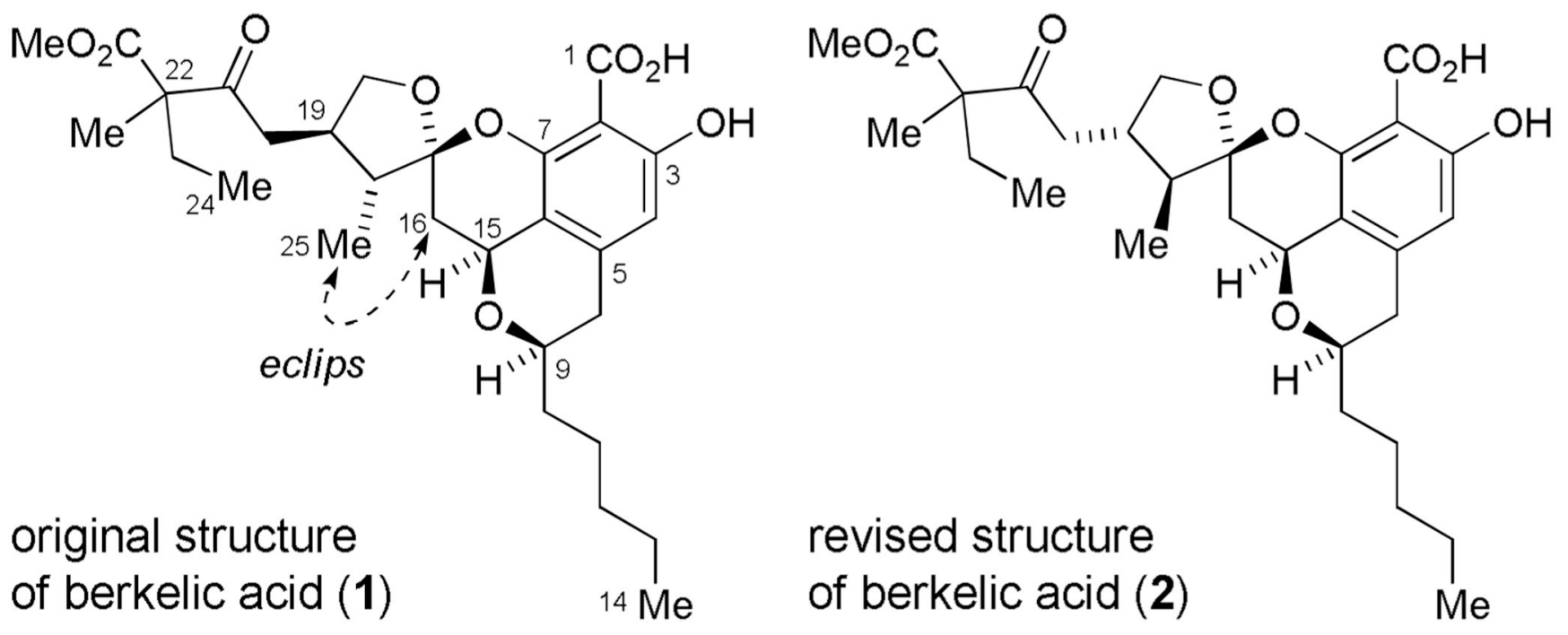

Figure 1.

Original and revised structures of berkelic acid. 

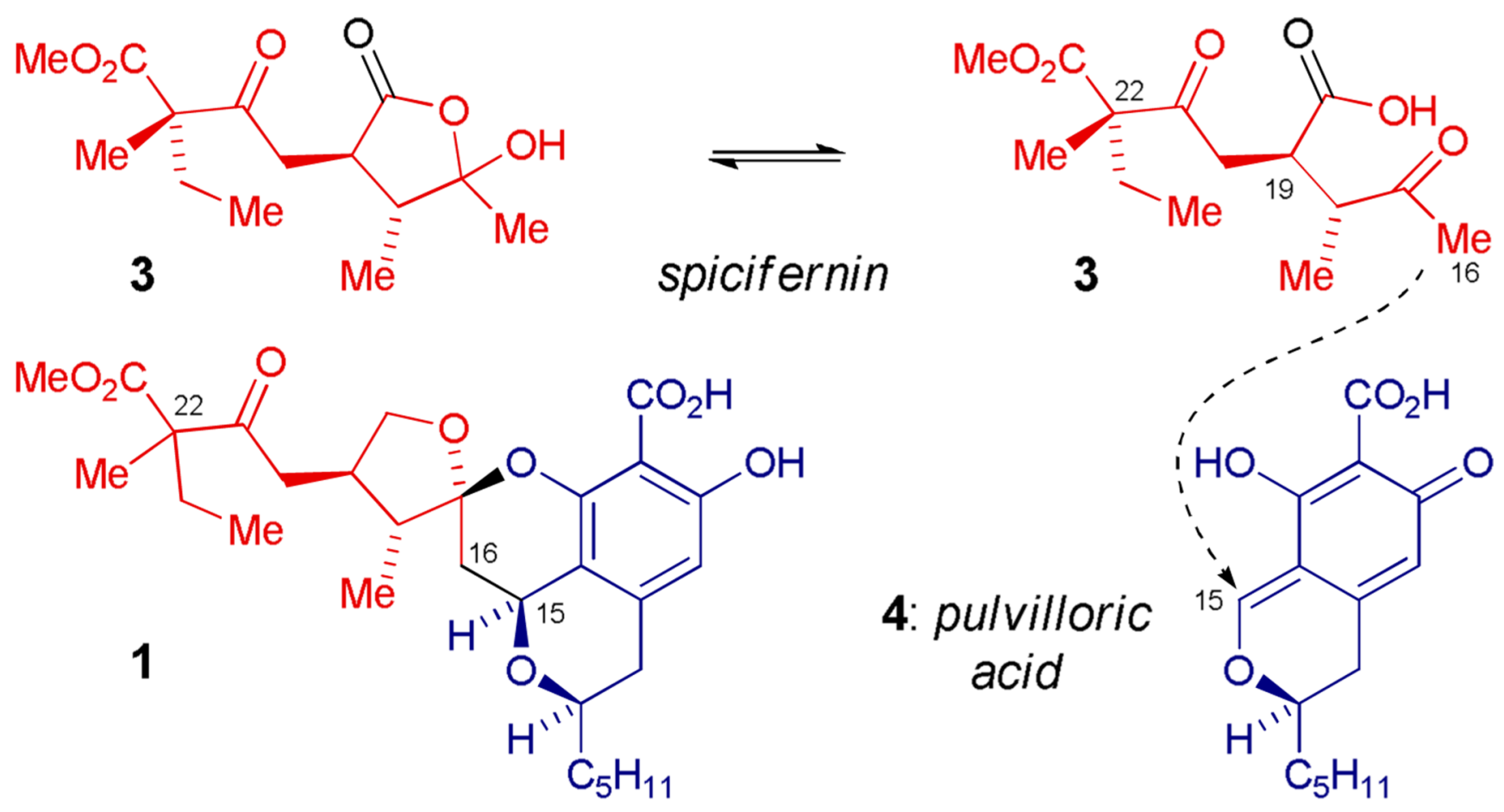

4: pulvilloric acid
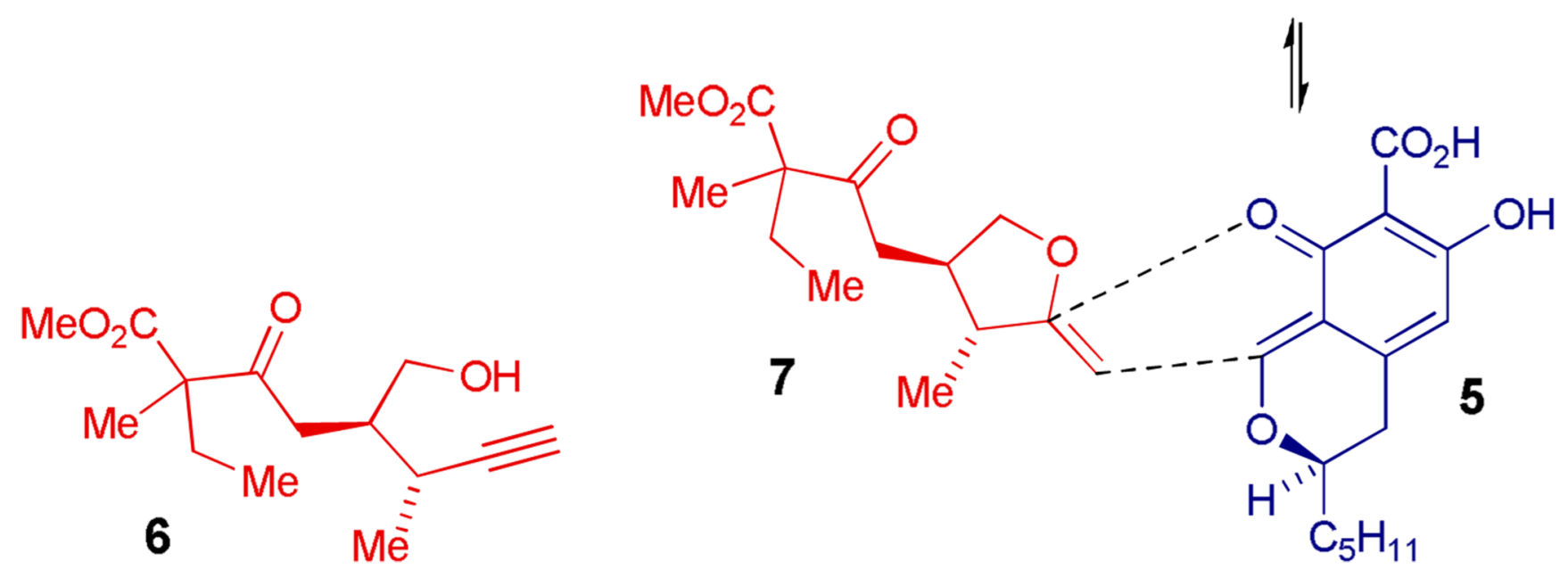

Scheme 1.

Synthetic Strategy 


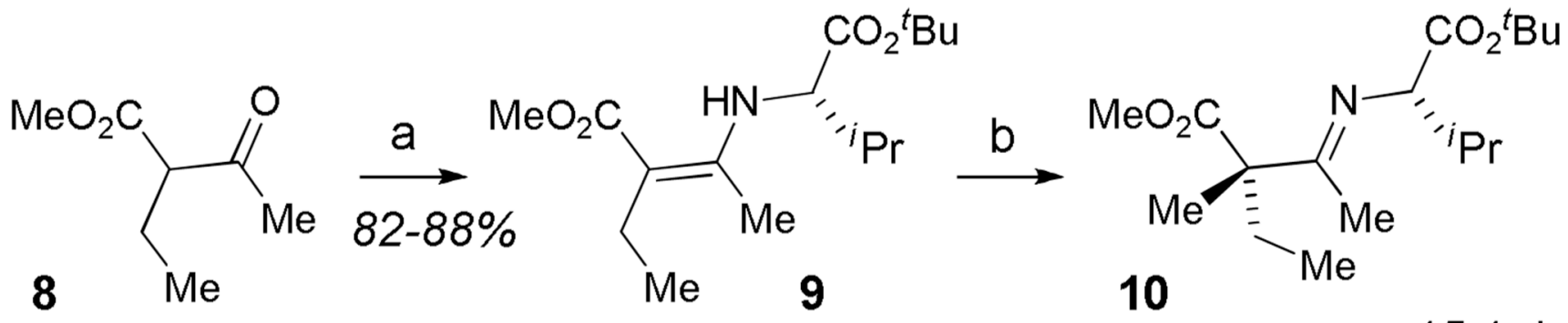<smiles>CCC#C[As]</smiles>

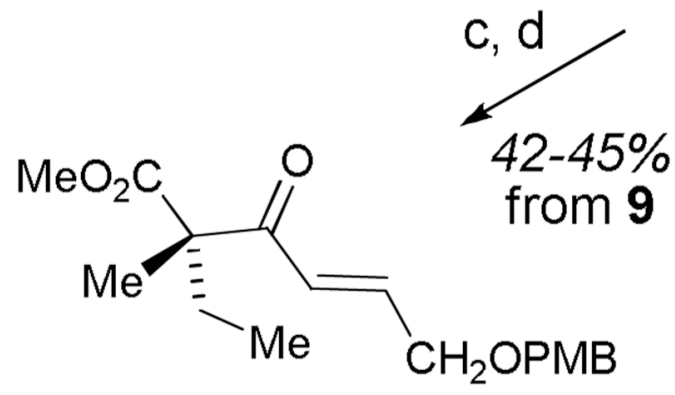

15:1 dr

12

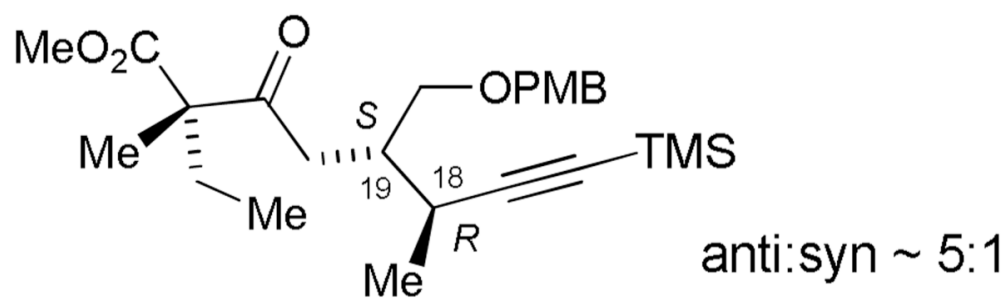

11<smiles>Cc1ccc(Br)cc1[N+](=O)[O-]</smiles>

$13 \mathbf{a}$ ( $+\mathrm{C}_{18}-\mathrm{S}, \mathrm{C}_{19}-\mathrm{R}$ diastereomer $\mathbf{1 3 \mathbf { b }} ; 1: 1$ ratio)

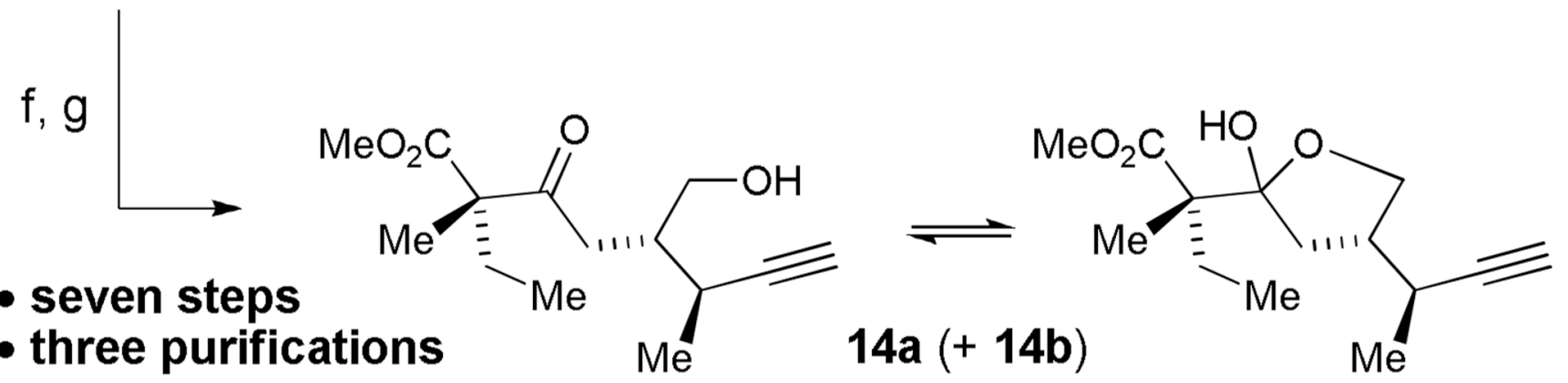

Scheme 2.

Synthesis of alkyne fragmenta

${ }^{a}$ Reagents and conditions: (a) $L-{ }^{t} \mathrm{Bu}-\mathrm{Val}-\mathrm{NH}_{2}, \mathrm{BF}_{3} \cdot \mathrm{Et}_{2} \mathrm{O}, \mathrm{PhH}$, reflux (82-88\%); (b) LDA, $\mathrm{PhMe},-78^{\circ} \mathrm{C}, 1 \mathrm{~h}$, THF (2.5 equiv. $),-78^{\circ} \mathrm{C}, 3 \mathrm{~h}$, MeI, $-78^{\circ} \mathrm{C}, 17 \mathrm{~h}$; (c) $1 \mathrm{M}$ aq. $\mathrm{HCl} / \mathrm{THF}$ (1:1), rt, $1 \mathrm{~h}$; (d) $\mathrm{TiCl}_{4}$, THF, 4 ÅMS, $0{ }^{\circ} \mathrm{C}, 30 \mathrm{~min}, \mathrm{NEt}_{3},-78^{\circ} \mathrm{C}, 1 \mathrm{~h}, \mathrm{PMBOCH}_{2} \mathrm{CHO},-78$ ${ }^{\circ} \mathrm{C}, 1.5 \mathrm{~h}, \mathrm{rt} 1.5 \mathrm{~h}\left(42-45 \%, 3\right.$ steps); (e) 1-trimethylsilyl-1-butyne, ${ }^{\mathrm{S}} \mathrm{BuLi}, \mathrm{THF},-78{ }^{\circ} \mathrm{C}, 2 \mathrm{~h}$, $\mathrm{CuBr} \cdot \mathrm{SMe}_{2},-78^{\circ} \mathrm{C}, 1 \mathrm{~h}$, then add $\mathbf{1 2},-78^{\circ} \mathrm{C}, 24 \mathrm{~h}$; (f) $\mathrm{K}_{2} \mathrm{CO}_{3}, \mathrm{MeOH}, \mathrm{rt}, 2 \mathrm{~h}$; (g) DDQ, $\mathrm{CH}_{2} \mathrm{Cl}_{2} / \mathrm{H}_{2} \mathrm{O}$ (7:1), rt (70\%, 3 steps); (h) 4-Br-2- $\mathrm{NO}_{2} \mathrm{PhNHNH}_{2} \cdot \mathrm{HCl}$, EtOH, reflux, $2 \mathrm{~d}$ (40\%, 2 steps). 
<smiles>[R]Oc1cc(O)c(C(=O)OC)c(CC(O)Cc2cc(O)c(C(=O)OC)c(OC)c2)c1</smiles>

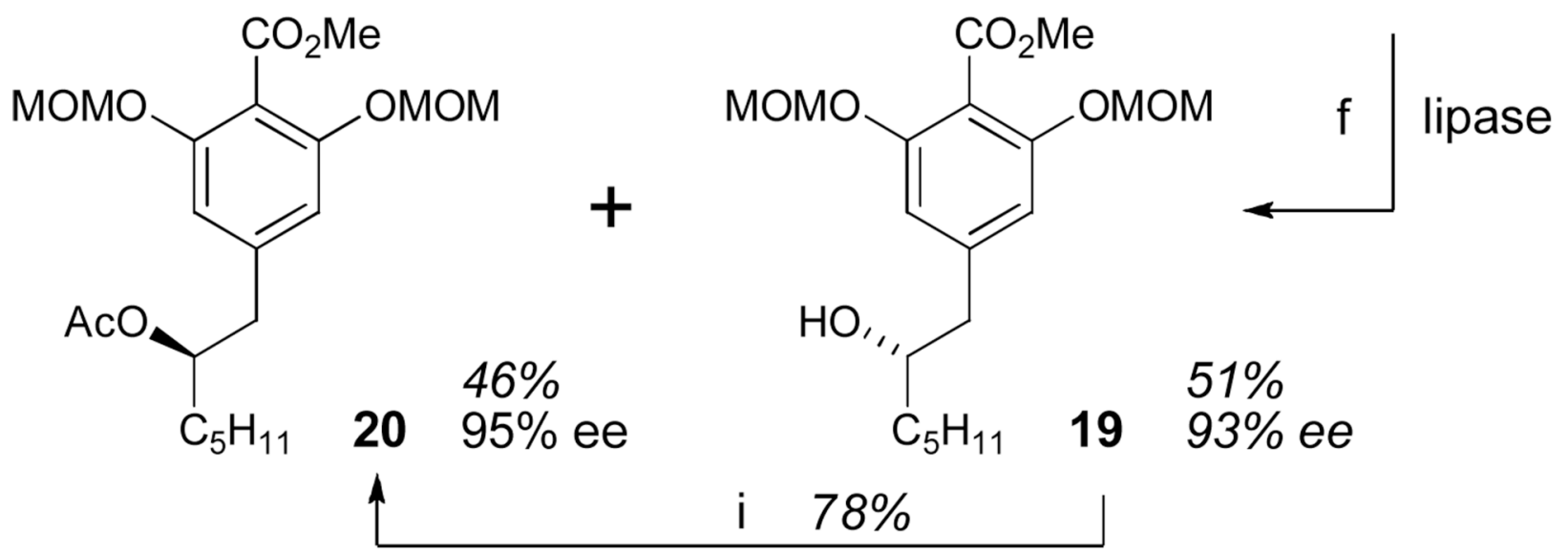

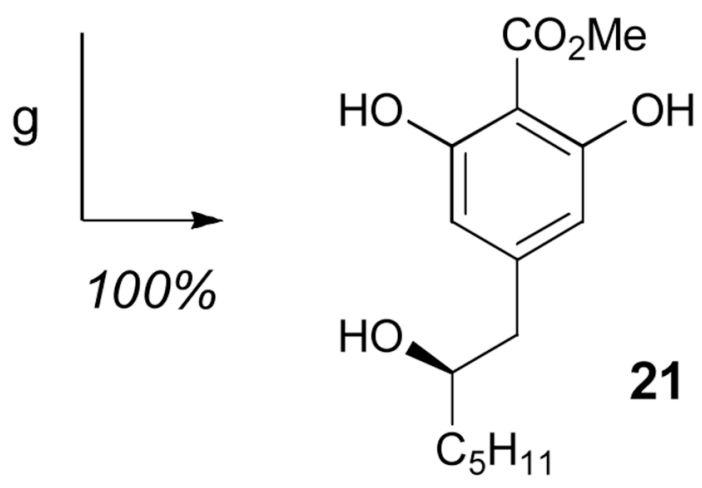<smiles>CCCCCCCCCCCCCCO</smiles>

Scheme 3.

Synthesis of aromatic fragmenta Reagents and conditions: (a) $\mathrm{Tf}_{2} \mathrm{O}$, lutidine, $\mathrm{CH}_{2} \mathrm{Cl}_{2}, 0{ }^{\circ} \mathrm{C}, 16 \mathrm{~h}(91 \%)$; (b) ${ }^{n} \mathrm{C}_{5} \mathrm{H}_{11} \mathrm{CHCHB}$ $(\mathrm{OH})_{2}, 5 \% \mathrm{Pd}(\mathrm{dppf}) \mathrm{Cl}_{2}, \mathrm{~K}_{2} \mathrm{CO}_{3}, \mathrm{THF} / \mathrm{H}_{2} \mathrm{O}$ (10:1), $\Delta, 2.5 \mathrm{~h}(91 \%)$; (c) $\mathrm{MOMCl},{ }^{i} \mathrm{Pr}_{2} \mathrm{NEt}$, $\mathrm{CH}_{2} \mathrm{Cl}_{2}, 0^{\circ} \mathrm{C} \rightarrow \mathrm{rt}, 18 \mathrm{~h}$; (d) $m \mathrm{CPBA}, \mathrm{CH}_{2} \mathrm{Cl}_{2}, \mathrm{rt}, 5 \mathrm{~h}$ (84\%, 2 steps); (e) $\mathrm{Pd} / \mathrm{CaCO}_{3}, \mathrm{H}_{2}$, $\mathrm{MeOH}, \mathrm{rt}, 20 \mathrm{~h}$ (90\%); (f) Lipase (Alcaligenes sp., lyophilized), MTBE, 4 AMS, vinyl acetate, rt, $7 \mathrm{~d}$; (g) $0.25 \mathrm{M} \mathrm{HCl}$ in $\mathrm{MeOH}, \mathrm{rt}, 15 \mathrm{~h}$ (100\%); (h) (EtO) ${ }_{3} \mathrm{CH}, \mathrm{TFA}, \mathrm{rt}, 15 \mathrm{~h}$ (99\%); (i) $\mathrm{PPh}_{3}$, DEAD, HOAc, PhMe, rt, 7 h $(78 \%)$. 


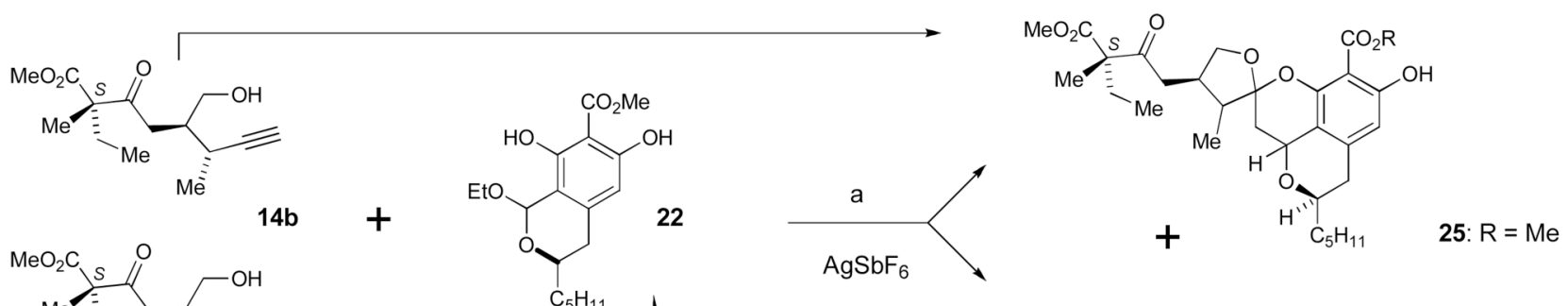<smiles>C#CC(C)C(CC(=C)C(C)(C)CC)CC(=O)O</smiles>

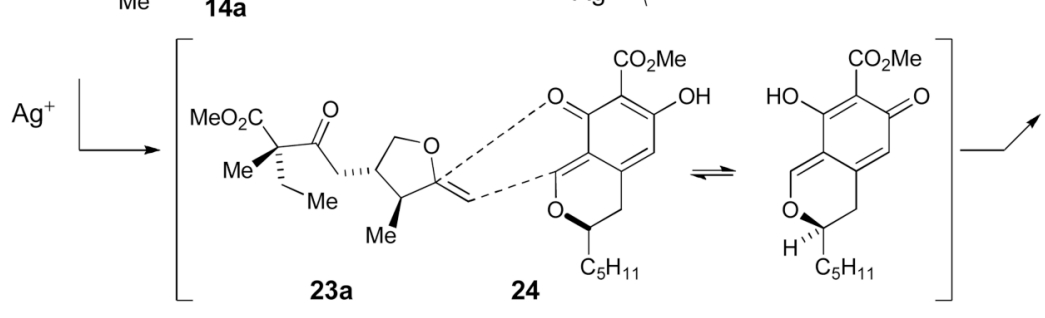

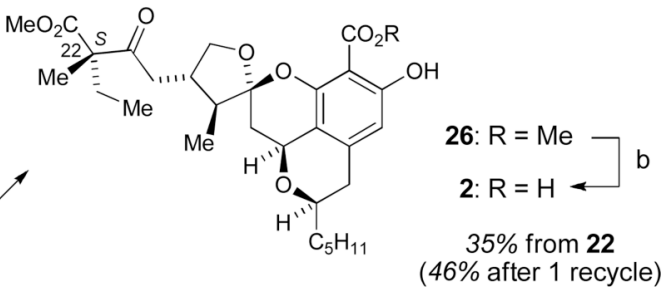

- 10 steps longest linear - $11-27 \%$ overall yield<smiles>C#CC(C)C(CO)CC(=O)[C@](C)(CC)C(C)=O</smiles>

ent-14a,b

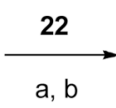

$\mathrm{a}, \mathrm{b}$

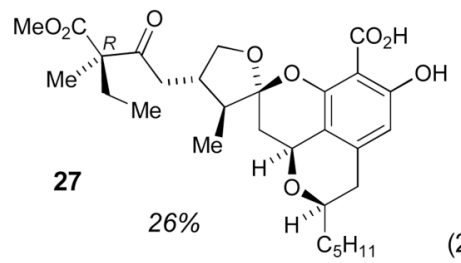<smiles>CCC(C)C(=O)C[C@H]1CO[C@]2(C[C@H]3O[C@H](CC)Cc4cc(O)c(C(=O)O)c(c43)C[C@@H]2O)O1</smiles>

Scheme 4.

Synthesis of berkelic acid (2) and C22- $R$ diastereomer 27a

${ }^{a}$ Reagents and conditions: (a) 14a,b or ent-14a,b (2.6 equiv.), 22 (1 equiv.), Et ${ }_{2} \mathrm{O}, \mathrm{rt}, 2 \mathrm{~h}$; (b)

$\left(\mathrm{Bu}_{3} \mathrm{Sn}\right)_{2} \mathrm{O}$ (35 equiv.), PhMe, $\Delta, 8 \mathrm{~h}$ for $2,14 \mathrm{~h}$ for 27. 